\title{
Uzbekistan: \\ A Critical Analysis of the Official Discourse on Terrorism
}

\author{
Tribedi CHUTIA
}

\begin{abstract}
Since its independence, Uzbekistan has often portrayed terrorism as one of the gravest threats to its sovereignty, integrity, unity, and internal stability. Uzbekistan's authoritarian regime has been perceived endorsing and executing a series of counter-terrorism policies to exorcise this hazardous threat that includes all possible tactics for eliminating terrorism from the respective region. Unlike the state's proclamation about the increasing gravity of the terrorist threat, some international human right organizations and Central Asian experts depict an opposite picture of it. They are seen to be very critical of the state's exaggerated version of the terrorist threat and question the state's intention behind such projection. This paper makes a systematic effort to critically examine how Uzbekistan's authoritarian leaders have constructed official discourse on terrorism, taking into consideration the social, political and economic context of the region. The paper also examines the authenticity of the state's continuous projection of terrorism to be one of the gravest threats to the sovereignty and integrity of the region by incorporating and analyzing a detailed account of the terrorist acts that have taken place in Uzbekistan since 1991 to 2018. Finally, the paper also explains why the Uzbek authoritarian regime is keen to construct terrorism to be one of the most dangerous threats to the state.
\end{abstract}

Keywords: terrorism, Uzbekistan, Counterterrorism Act, security, non-state actor.

Tribedi CHUTIA

$\mathrm{PhD}$ Research Scholar,

Centre for Russian and Central Asian Studies,

School of International Studies,

Jawaharlal Nehru University, New Delhi

Email: tribedichutia7@gmail.com

Conflict Studies Quarterly

Issue 37, October 2021, pp. 21-35

DOI: $10.24193 / \mathrm{csq} .37 .2$

Published First Online: 05 October /2021

\section{Introduction}

In today's global world, the term 'terrorism' has become so familiar that it can be compared with an ingredient like the potato in North Indian cuisines every day and everywhere in all North Indian dishes. The media, more particularly some of the electronic channels, by using graphical design and sound, display the news of terrorist attacks in a very excited but horrific way, 
implying that the terrorists involved that attacks (if they escape alive) themselves feel exotic for their deeds. On the other hand, civilians get frightened to step outside their homes. Simultaneously, in such cases, the state machinery often leaves no stone unturned to prove the inference that terrorism is the principal threat to the sovereignty and integrity of the state and the whole world community.

However, the studies and statistics related to the past terrorist attacks' casualties reflect a different picture against the state's projection. The research shows that the terrorist attacks in the last two decades cost far fewer human lives than those killed by poverty, hunger, and climate change. For example, the Global Terrorism Index (2019) has figured the death of 15,952 persons (Afghanistan - 7,379, all other Countries 8,563) from terrorism in the year of 2018.

On the contrary, the World Health Organisation (WHO) (2019) has reported that in 2018, an estimated 6.2 million children and minors under the age of 15 years died, commonly from "preventable causes" such as pneumonia, birth asphyxia, congenital anomalies, diarrhea and malaria. These can be prevented or treated with "simple, affordable interventions" containing vaccination, sufficient nutrition, drinking water and foodstuff and proper care by a skilled health provider when required.

Similarly, according to Kofi Annan's think-tank, a well-known global humanitarian forum, "global warming costs 300,000 human lives a year" (Vidal, 2009). The World Health Organization's report on "Climate Change and Human Health" has noted that climate change is "expected to cause approximately 250000 additional deaths per year between 2030 and 2050" (WHO, 2018). The above argument does not mean that terrorist activities should be justified. Nevertheless, at the same time, the intense and intention of the state's response to terrorism should also be critically reexamined, which is often trapped in power politics and the unfolded ambitions of the regime. However, before analysing in details about the official discourse on terrorism, it is pertinent to sketch a brief overview of Uzbekistan for understanding the social-political and economic dimension of the region.

\section{The Republic of Uzbekistan: An overview}

Uzbekistan is one of the largest countries in Central Asia. It emerged as an independent state on August 31, 1991, following the disintegration of the Soviet Union. Geographically, Uzbekistan is situated in "the heart of Central Asia" and on "the ancient Great Silk Road between Asia and Europe" (Country Watch, 2015). Being the third-largest country in Central Asia, it covers an area of 447,000 square kilometers. It is the only country in Turkestan that shares borders country in the region. Uzbekistan shares its boundary with Kazakhstan in the north and the Republic of Kyrgyzstan in the north-east. The south-east shares a border with Tajikistan and Turkmenistan in the southwest, and Afghanistan in the south. About $80 \%$ of Uzbekistan's landmass is surrounded by plane 
desert or semi-desert, with the vast Kyzyl-Kum Desert filling its northern lowlands. "To the south-east are the foothills of the Tien Shan, which rise steadily to heights reaching 4,500 meters above sea level" (Asian Development Bank, 2010) . Uzbekistan also has a short border with Afghanistan, which is considered one of the world's most unstable countries. Uzbekistan is a dry, landlocked country. Being entirely bordered by landlocked countries, Uzbekistan is also called a doubly landlocked country.

While looking at Uzbekistan's economic prospects, it is observed that Uzbekistan is one of the largest cotton producer countries in the world. At present, it is the eighth-largest cotton producer and the eleventh-largest cotton exporter in the world. Moreover, Uzbekistan is also rich in natural resources like hydrocarbon, gold, copper, and uranium.

Demographically, Uzbekistan, being the most populous country in Central Asia, has a population of approximately 32 million. It is important to note that it is one of the poorest countries in Central Asia, and most of the people are still dwelling in rural areas which are heavily dependent on cotton farming for their livelihood. The United Nations Development Programme's report on "Poverty, Inequality, and Vulnerability in the transition and developing economies of Europe and Central Asia" (2014) has indicated the pathetic conditions of the people of Uzbekistan. According to this report, if the "Purchasing Power Parity (PPP)\$4.30/ Day poverty line is treated as a regional income poverty threshold and if PPP\$ 2.15/Day is accepted as a regional threshold for extreme income poverty", then, the people who live in extreme income poverty in Uzbekistan would be more than 10 million. Naturally, this data speaks a lot about the contemporary socio-political and economic situation in the region.

Ethnographically, Uzbekistan has numerous ethnic groups. However, the most dominant ethnic group in Uzbekistan is the ethnic Uzbeks. It comprises $80 \%$ of the total population. According to the statistics of the Government of Uzbekistan, over 129 ethnic groups are living in Uzbekistan. (Country Watch, 2015) Since independence, Uzbekistan has taken the membership of some regional and international organisations. At present, it is a member of United Nations, Eurasian Economic Community (Eurasec), Commonwealth of Independent States (CIS), Shanghai Cooperation Organization (SCO), Economic Cooperation Organization (ECO) and Central Asian Cooperation Organization (CACO). It also joined the Georgia, Ukraine, Azerbaijan and Moldova (GUAM) alliance in1997 but formally withdrew from it in 2005 (Sevim \& Rozanov, 2014).

\section{A brief accounts of terrorist attacks}

Independence from the Soviet Union had never been a long waiting and precious dream for the Uzbek leaders and its citizens; neither had they fought the years-long struggle to accomplish it. Instead, some scholars like Ajay Patnaik, Mariya Omelicheva, and others argue that like other C.A. states, Uzbekistan was heavily dependent on the USSR's economic aids had hardly had any preparation to be disintegrated from it. However, after 
obtaining independence, protection and preservation of sovereignty and integrity of the state have become the first and foremost raison d'état of the C.A. states for which they have been consistently working since independence. The President of Uzbekistan, Islam Karimov, proved himself as more aggressive in zealously preserving the states' raison d'état at any cost. The disintegration of the USSR which brought about unexpected sovereignty to the C.A. states ushered in some non-traditional security threats like arms smuggling, drug trafficking, environmental degradations, religious extremism, and terrorism. Hence, Uzbekistan's government has been steadily expressing concern on the alleged grave security threat posed by the religious extremism and terrorism since the early 1990s.

Contrary to the government's projection, Uzbekistan did not experience any severe terrorist attack until 1999. However, violence erupted in Namangan province in December 1997 where the Islamic insurgent groups murdered many police personnel and beheaded two others, a government official and a prominent community member. The government wasted little time in arresting several hundred people for alleged connections with the tragic incident in response. The response of the government was so massive and aggressive that within four months, more than one thousand people were arrested from the Ferghana strongholds of Namangan and Andijan provinces (Crosston, 2006).

Uzbekistan experienced the first major terrorist attack at the very beginning of 1999 . On February 16 of that year, five bombs exploded near the government buildings in Tashkent, claiming the lives of 16 persons and wounding more than 100 others. It was an unprecedented attack in a former Soviet state U. S. Department of State, 2000).

Another severe terrorist incident took place in Uzbekistan in March 2004. It was the first reported suicide bombing in Central Asia. After a blast at a safe house in Bukhara, "suicide bombers attacked a popular bazaar and other locations in Tashkent, causing the deaths of more than a dozen police officers and innocent bystanders and tens of injuries" (U.S. Department of State Country Reports on Terrorism 2004 - Uzbekistan). An ambiguous Islamic Jihad group of Uzbekistan claimed responsibility for this attack. It is to be noted that Islamic Jihad group of Uzbekistan is reportedly an alias of the IMU or a splinter group of the IMU that has changed its name "to the Islamic Jihad Union(IJU) in 2005" (Nichol, 2010).

Suicide bombing again occurred in Tashkent on July 30, 2004. At 5 pm, on that day, three nearly simultaneous bomb blasts raged through Uzbekistan's capital outside the overwhelmingly guarded U.S. and Israeli embassies and the headquarters of the Uzbek chief prosecutor. According to news report of Washington Post (July 31, 2004) at least two security guards were killed and more than five individuals got wounded in this attack. Although the primary target of the terrorists was the diplomatic personnel of the embassies, no employees of embassies were killed or wounded in this incident. 
The IMU and IJG took responsibility and clarified that the "bombings were aimed at the Uzbek and other apostate government" (Nichol, 2010).

Uzbekistan's government has also been vigorously projecting the bloody Andijan massacre, (infamous for massive human rights violation) as a pre-planned terrorist act and blamed IMU members and Hizb ut Tahir for provoking violence to destabilise the government. The Andijan massacre took place on May 13, 2005, where the Uzbek military force indiscriminately fired on protesters resulting in the death of dozens or conceivably hundreds of noncombatants and countless injuries that arose severe human rights concerns all around the world.

On May 25-26, 2009 another minor attack erupted in the border town of Khanabad where the terrorists attacked a police checkpoint situated near the Uzbek Kyrgyz's border that cost the life of at least one police personnel and injured several onlookers. Four bombs exploded in Andijan in the commercial district in which numerous deaths and injuries were alleged. The Uzbek Government blamed IMU for this attack, but, IJU allegedly claimed responsibility (START, 2016)

Another shoot-out incident in Tashkent in September 2009 between government authorities and alleged extremists caused three IMU associates' lives. The Uzbek authority also claimed this group's direct involvement in the 1999 blast and recent assassination in Tashkent.

In November 2011, another explosion incident was reported in the South of Uzbekistan that damaged a railway bridge that connected Termez and the town of Kurgan-Tyube in Tajikistan. Uzbek law enforcement authorities declared the bombing "a terrorist act", but no one asserted responsibility. "No casualties were recorded as a result of the explosion" (START, 2016) (. Nonetheless, it is repeatedly alleged by the human rights organisations and political opposition that Uzbekistani authorities often overlaps any violence with the terrorist acts to portray the gravity of the terrorist threat and justify the draconian counter-terrorism measures of the government.

\section{Examining official definitions of terrorism}

The government of Uzbekistan often perceives as a severe victim of terrorism and is showing its uncompromising commitment to eliminate all the possible threats posed by terrorist groups to the security and sovereignty of the republic. It has enacted a series of counter-terrorism laws for efficiently dealing with the issue. The official documents from which the official definitions of Terrorism in Uzbekistan have been clustered are as follows.

- Criminal Code of the Republic of Uzbekistan 1994

- Law of the Republic of Uzbekistan on Combat of Terrorism 2000

- Act on combating the legalisation of income derived from criminal activity and financing of terrorism 2004. 
The Criminal Code of the Republic of Uzbekistan enacted in 1994 has provided an inclusive definition of terrorism. The principal purpose of the code is to define grounds and principles of obligation, determine how the socially dangerous acts are to be recognised as crimes, and prescribe punishments and other actions of legal influence that may be used on persons who perpetrated socially dangerous acts. It has prescribed various legal actions for different terrorism-related crimes. The code has defined terrorism as a socially dangerous act. It has incorporated a series of articles that determine liability both directly for terrorism (article 155 "Terrorism") and for crimes that are instrumental to the grounding and enactment of terrorist acts, including "smuggling of various types of weapons and their ammunition" (article 246 "Smuggling").

Further, the code also includes deliberate acts related to the "illegal circulation of weapons" (Article 247), "Illegal procurement of firearms, ammunition, explosive substances or explosive devices" as a terrorist offence. Eventually, the code incorporates the activities such as the "negligent storage of firearms and ammunition within the boundaries of terrorist crimes" within the sphere of terrorist crime (Government of the Republic of the Uzbekistan, 1994).

Article 155 of the Criminal Code of the Republic of Uzbekistan (CCRU) (1994) which directly deals with terrorism has defined terrorism as follows:

Terrorism, that is, violence, use of force, or other acts, which pose a threat to an individual or property, or the threat to undertake such acts in order to force a state body, international organisation, or officials thereof, or individual or legal entity, to commit or to restrain from some activity in order to complicate international relations, infringe upon the sovereignty and territorial integrity, undermine the security of a state, provoke war, armed conflict, destabilise the socio-political situation, intimidate the population, as well as an activity carried out in order to support the operation of and to finance a terrorist organisation, preparation and commission of terrorist acts, direct or indirect provision or collection of any resources and other services to terrorist organisations, or persons assisting to or participating in terrorist activities (Government of the Republic of Uzbekistan, 1994, p. 46).

The code has also fixed and prescribed different penalties for the terrorist activities depending on the crime's gravity. The law establishes punishment with imprisonment from ten to fifteen years for those terrorist activities which attempt "to the life of or infliction of bodily injury to a state official or public figure or representative of authorities", perpetrated in association with their State or public activities. Such activities must be committed for the "destabilization of situation or influence upon decision making by government bodies or impediment to political or other public activity" (Government of the Republic of Uzbekistan, 1994). 
Further, the code has added that if the actions mentioned above cost an individual's life or create other grave consequences, then the convicted shall be awarded punishment with imprisonment for fifteen to twenty years or capital punishment.

In this regard, it is noteworthy to mention that Uzbekistan's criminal code also prescribes harsh punishment to less dangerous acts such as direct or indirect connection with the creation of banned organisations or disseminating materials and publications intended to undermine state public order, etc. These are considered a criminal offence and sentenced to long terms of 10-25 years (Omelicheva, 2011).

\section{The Law of the Republic of Uzbekistan On Combat of Terrorism}

The Republic of Uzbekistan's primary legislation on countering terrorism entered into force on December 14, 2000. The main objectives of the law stated in Article 1 are to "ensure security to individual, society, and state from terrorism", "protection of sovereignty and territorial integrity of the state" and the maintenance of "civil peace and national accord". This law has clarified the notions about the specific commonly used terminology of terrorism discourse such as 'hostage,' 'terrorism,' 'terrorist organisations' 'terrorist actions' and so on. It also incorporates a lengthy definition of terrorism and a detailed account of all those activities included under the ambit of terrorist actions. The definition of terrorism presented in the law is almost the same as the definition incorporated in Article 155 of the Criminal Code. It defines Terrorism as:

Violence, threat of violence or other criminal acts, which cause danger to life and health of a person, of destruction (damage) of property and other material objects, and which are intended to force the state, an international organisation, physical or juridical person to undertake or withhold of undertaking of certain actions, to bring tension into international relations, to violate sovereignty, territorial integrity, to undermine security of the state, to provoke armed conflicts, to frighten population, to destabilise social-political situation, in order to reach political, religious, ideological and other aims, which are punishable under Criminal Code of the Republic of Uzbekistan. (Government of the Republic of Uzbekistan, 2000, p. 3)

The law has encompassed an extensive list of activities within the sphere of terrorist actions. The list includes:

taking and keeping hostages, infringement on the life of public figure, the representatives of national, ethnic, religious, and other groups of the population, foreign countries and international organisations; seizure, damage, destruction of the public or civil objects. Similarly, the actions like explosion, arson, deployment or threat of deployment of explosive devices, radioactive, biological, explosive, chemical and other hazardous substances are also the examples of terrorist 
actions incorporated in this law. (Government of the Republic of Uzbekistan, 2000, p. 3)

The list has also contained a couple of other activities namely "the seizure, hi-jacking, damage, destruction of overland, water, and air transport means", and so forth. Simultaneously, "the creation of panic and provocation of disorder in the area of public gathering and during public events" and the other deliberate acts such as "causing harm or threat to life, health and property of individuals or juridical entities by way of setting up crashes, catastrophes of man-caused character"; spreading of threats by various means and methods are considered as terrorist acts. Eventually, the list may include "any other actions of the terrorist character, which are determined as such by the legislation of the Republic of Uzbekistan and by universally recognised norms of international law". All these acts, as mentioned above, are liable to legal action (Government of the Republic of Uzbekistan, 2000).

\section{Labeling terrorism as the special grave crime}

While looking at the official documents related to terrorism and counteraction to terrorism, adopted and implemented by Uzbekistan, it is observed that there are many articles in these official documents that directly recognise terrorism primarily as 'criminal act'. These documents have not confined terrorism too merely as a criminal act. Instead, they have distinguished terrorism from the petty, average, and grave crime categories and have placed terrorism as the 'special grave crime'. For example, in chapter 8, article 155 of the Criminal Code of the Republic of Uzbekistan (1994) has declared terrorism as a crime against "peace and humanity". The language of the Code concerning Terrorism is such that it does not present terrorism only as a crime. Beyond it, the code constructs terrorism as one of the gravest crime and one of the most dangerous threats to peace and humanity by prescribing punishments for specific terrorist acts with imprisonment up to 20 years or capital punishment. Such long-term imprisonment or capital punishment is established by the code only for those recognised as "especially serious crime". In this regard, it is essential to note that the law has defined 'crime' as "culpable socially dangerous act".

Further, it has divided crime with "insignificant social danger; less serious; serious; and especially serious depending on the grounds of character and degree of the crime" (Government of the Republic of Uzbekistan, 1994). Moreover, the code has also criminalised a long list of intentional acts by incorporating them within terrorist actions. Similarly, the Republic of Uzbekistan's law on Combat of Terrorism (2000) has also used the same language and has constructed terrorism as 'criminal acts'. 


\section{Constructing distinct identity to the terrorist by using emotive words}

The use of emotive language plays a vital role in branding terrorism as something more than merely a criminal act. It constructs terrorism as inimical to the constitutional principles and values of the state. The primary purpose of using emotive language to denounce terrorism is to create a distinct identity of the terrorist, which is defined as opposite to the self-defined identity of the 'commons' by the state. The terrorism-related official documents of Uzbekistan contain many emotive and derogatory words to describe terrorist actions and terrorist. The use of emotive language in denouncing terrorism and terrorist acts is widely seen in the Uzbek leaders' speeches and statements. Islam Karimov, the founding president of the Republic of Uzbekistan, is the most prominent regarding it. In his address at the Euro-Atlantic Partnership Prague Summit held on November 22, 2002, Karimov described terrorism as "the most dangerous challenge to the contemporary civilisation". He also used some other emotive words such as "deadly", "inhumane", "monstrous" to describe terrorist threat (NATO, 2002).

Just after a series of six-car bombing in Tashkent in February 1999, Islam Karimov, without mentioning the word 'terrorism' or 'terrorist', expressed his response in the following words-"I am prepared to rip off the heads of 200 people, to sacrifice their lives, in order to save peace and calm in the Republic" (Roth, 2016).

Another notable example of describing terrorism with emotive words by the Uzbek authority is contained in the U.N. official document. Addressing the fifty-sixth U.N. General Assembly session, Abdulaziz Kamilov, Minister for Foreign Affairs of Uzbekistan coined terrorism and drug trafficking as "the principal threats to the present and future of humankind". In the same speech, he described terrorism as "a plague of the twenty-first century that can enter any household" (United Nations General Assembly, 2001). Such emotive language is used to construct a distinct, monster-like identity of terrorism and terrorist, which is opposite to the self-defined liberal, democratic, secular character of the state.

\section{Projecting terrorism as an act perpetrated solely by non-state actors}

While observing Uzbekistan's official records that primarily deal with the phenomenon of terrorism and terrorism-related criminal infractions, it is noticed that these documents represent the state-centric bias by structuring terrorism as an act perpetrated mainly by non-state actors. These documents have defined terrorism as an act committed by only a group of individuals with prior agreement or an organised group. Moreover, these documents also describe terrorism as those criminal acts that endanger the sovereignty, territorial integrity and public security of the state. By doing so, they rule out the possibility of involving the state in perpetuating any terrorist act. For example, the Law of the Republic of Uzbekistan on Combat of Terrorism (2000) has defined "terrorist group" as "a group of persons, who committed according to the prearranged 
plan of terrorist action, preparation of terrorist action or attempt of its committing". This law has defined "terrorist organisation" as "stable association of two or more persons or terrorist groups to conduct terrorist activity" (Government of the Republic of Uzbekistan, 2000). Both these definitions describe terrorism as an act committed by "a group of persons". The non-state nature of the terrorist act has been reaffirmed in the definition of terrorism contained in this law. This law defines terrorism as "violence, the threat of violence or other criminal acts... to violate sovereignty, territorial integrity, to undermine the security of the state... To reach political, religious, ideological and other aims" (Government of the Republic of Uzbekistan, 2000). By defining terrorism as an act committed to violating sovereignty, territorial integrity and security of the state, the law has directly discarded the perspective that assumes the state as the potential perpetrator of the terrorist act.

\section{Is terrorism posing dangerous threat to Uzbekistan?}

Islam Karimov, the Republic of Uzbekistan's founding president till his death in September 2016 had been continuously portraying terrorism as the most dangerous threat to the state's stability and security. Nonetheless, instead of the official projection and proclamation on the gravity of the terrorist threat, a considerable number of international non-governmental human rights organisations such as the "Human Rights Watch (HRW)", "the International Crisis Group (ICG)”, are seen depicting a different picture regarding it. The reports based on extensive research and rigorous field study published by these organisations have negated the Uzbek government's claim on terrorism as one of the most dangerous threats to the state's security and stability (For example World Report 2016, U.S. Department of State' Annual Country report on terrorism). Similarly, many Central Asian experts, such as Mariya Y. Omelicheva (2011), Vitaly V. Naumkin (2005), David Lewis (2014), Sarah Lain (2016), Stuart Horsman (2008), have also reaffirmed the depiction of these organisations by arguing that the Central Asian states to a large extent have exaggerated the gravity of the threat posed by terrorism. The paper has analysed two popular open-source data on global terrorist incidents, namely, Global Terrorism Database and RAND database to examine the gravity of the terrorist threat to Uzbekistan's sovereignty and integrity. The database includes various essential information about terrorist incidents such as the number of events, the perpetrators' name, the number of fatalities and injuries. The data available in GTD and RAND have clarified that significantly fewer terrorist incidents have taken place in Uzbekistan than the other terrorist affected countries of the globe. According to the GTD data, Uzbekistan has faced 18 terrorist incidents from 1992 to 2018.

All these incidents have been recognised as terrorist acts on the grounds of the criteria, made by this database. According to this data, the number of total fatalities in all these incidents is fifty-eight, and one hundred sixty-six people have been reported to be injured. Out of the total, four incidents do not cost any fatality. The data has also reflected 
a drastic decrease in terrorist incidents in Uzbekistan since 2005. The most important thing is that the only terrorist attack that cost 23 human lives is also seen intermingling with disputes regarding the perpetrators' identity. A considerable number of experts have very critical views about this incident. They have suspected government security forces' involvement in perpetrating such incidents to continue wide-scale suppression on the state's anti-government forces. Significantly, out of the 18 incidents, the perpetrator of the 14 incidents have been listed as unknown.

Another open-source database on terrorism, namely the RAND Database of Worldwide Terrorism Incidents has also reported sixteen terrorist attacks happened in Uzbekistan from 1992 to 2010. According to this database, 163 people were injured, and the number of casualties was 37 in these incidents (RAND,1994). Like the Global terrorism database, it has also reported a massive reduction of Uzbekistan terrorist attacks since 2005. This database has listed only three incidents in terrorist nature which were taken place between 2005 to 2010 .

\section{Examining the gravity of state repression}

This paper has already explained how Uzbekistan's terrorism-related official documents have constructed terrorism as an act committed solely by non-state actors. The tendency of excluding the state from the label of terrorist has assigned sole legitimate power to the state to use violence against anyone if the state believes it necessary to do so. The concentration of the legal power of using force or violence upon a single entity may have brought the chance of misusing this power by that entity. One should keep in mind that the state is an abstract concept that inherently deserves idealism, but the individual or the group that regulates the state is neither abstract nor ideal. Lord Acton rightly asserts, power tends to corrupt, and absolute power corrupts absolutely.

While enquiring the perpetrators of the frequently occurred violent incidents in the surrounding, Richard Jackson (2007) has put forward an important statement. He has stated that if the use of violence or the threat to use force for political objectives is considered as a terrorist act, then the state itself has committed a large number of such violence. The Central Asian countries are fit for this assertion, which has long been known for exercising the widespread scale suppression and violence against the political opponents, radical religious groups, and any anti-government voice in the state.

The ample examples of perpetrating indiscriminate and ruthless violence against civilians by the Central Asian countries' government are found in various human rights organisations' various reports. The government used to execute massive and brutal crackdown on the selected individuals or the group more acutely when it is followed by immediately occurred alleged terrorist attack. For example, in Uzbekistan, just after the serial car bombing in Tashkent in 1999, Uzbekistan's government accused the IMU of committing this terrorist act and started a large wave of repression. A total of 
twenty people appeared before the court on the charge of attempting to assassinate Karimov and overthrow the government (Naumkin, 2005). The court conducted this trial in closed-door and declared all of them as guilty. Finally, the court sentenced six defendants to the highest penalty- execution by firing squad. The others received punishment with imprisonment for ten to twenty years (Naumkin, 2005). The Uzbekistani authorities continuously ruled with an iron fist by exercising arrest, torture, and repression as the most appropriate method of maintaining the state's security and stability. The International Religious Freedom report, published by the U.S. Department of States noted that "there were about 300 arrests in the first seven months of 2002 on religious or political grounds, compared with 1500 on average in any seven months in 1999-2001" (U.S. Department of State, 2002).

Uzbekistan authorities again unleashed a comprehensive campaign of arrests of persons soon after the occurrence of March 2004 terrorist attacks. According to the reports, about four hundred people were arrested in connection with this attack (Naumkin 2005). In this attack, for the first time in Uzbekistan women suicide bombers were observed. Regarding women's suicide bomber involvement in this terrorist incident, the Central Asian Expert 0 Roy made a significant comment. Roy stated, "as far as we know, most of the suicide bombers were just members of families whose members are in jail, and it was some protest against the police in Uzbekistan" (Pannier, 2004). The similar kind of widespread crackdown was also noticed soon after the failed attempt by an unknown gunman to assassinate Saparmurat Niyazov, the president of Turkmenistan in 2002. As a result, the criminal police arrested, tortured, and tried about 100 persons connected with that attack (Omelicheva, 2007).

The most significant example of the brutal suppression of public unrest is the May 2005 Andijan event. On May 13, the Uzbekistani police force allegedly fired upon the protesters gathered in Andijan, Uzbekistan. The protesters who also included children and women were mostly unarmed. The indiscriminate firing by the Uzbekistani police force resulted in the death of about 137 persons and hundreds of injuries (Human Rights Watch, June 2005). This violence's intensity was so intensive and inhumane that the U.S. and many other Western countries demanded an independent international investigation into this incident. However, Uzbekistan rejected any international demand enquiry. The report on International Religious Freedom, 2015 has stated that there are estimated between 5,000 and 15,000 individuals remained in prison on charges related to "religious extremism" or membership in an illegal religious group in Uzbekistan according to independent human rights group (U.S. Department of State, 2015).

The World Report has also reinforced various other human rights organisations' claims regarding the Uzbek authorities' massive repression. It has reported that the Uzbek government has imprisoned thousands of people on politically motivated charges to impose its suppressive rule, targeting human rights and opposition activists, journalists, 
religious believers, artists, and other perceived critics (Human Rights Watch, 2015:599). In a nutshell, the Uzbek government has been continuously exercising state repression as an appropriate means of protecting and preserving the statuesque in the region which is often termed as the authoritarian, super-presidential and dictatorial regime.

\section{Conclusion}

The analysis and explanation of this paper on the official discourse of terrorism have reflected two crucial aspects. Firstly, the data of terrorist incidents in Uzbekistan during 1992-2018 has identified most terrorist attacks as minor, less significant and small scale on the grounds of its nature and degree. If the Uzbek State has intended to designate terrorism as one of the most dangerous threats to the country's stability and security on the grounds of these fewer, minor terrorist events, it would be a more exaggeration than the real. Secondly, the data provided by different international human rights organisations have demonstrated that the state authorities have perpetrated much more political murder and violence incidents than the number of terrorist attacks committed by non-state actors in Uzbekistan.

By summing up, it is essential to reaffirm that this paper does not justify any act of violence perpetrated by the terrorist groups. This research has only challenged one dominant approach to the study of terrorism that recognises the non-state actors as the sole perpetrator of terrorism by referring to Uzbekistan's examples. It has argued that terrorism is an act that can be performed by both the state and the non-state actors. This paper has also carefully investigated how the state used to misuse the sole legitimate power of using violence to preserve the status quo, existing regime, and suppressing the political opponents and government critics' voices.

\section{References}

1. Asian Development Bank. (2010). Central Asia atlas of natural resources. Central Asian Countries Initiative for Land Management Asian Development Bank. Asian Development Bank.

2. Crosston, M. (2006). Fostering fundamentalism terrorism, Democracy and American engagement in Central Asia. Ashgate Publishing.

3. Country Watch. (2015). Uzbekistan 2015 country overview. Retrieved from http:// www.countrywatch.com/Content/pdfs/reviews/B46Z4Q93.01c.pdf.

4. Government of the Republic of Uzbekistan (1994). Criminal Code of the Republic of Uzbekistan, the Oliy Majlis of the Republic of Uzbekistan, Tashkent. Legislation Online. Retrieved from https://www.legislationline.org/documents/action/popup/id/8931.

5. Government of the Republic of Uzbekistan (2000). Law of the Republic of Uzbekistan on Combat of Terrorism, The Oliy Majlis of the Republic of Uzbekistan, Tashkent. Legislation Online. Retrieved from http://www.legislationline.org/documents/action/ popup/id/7633. 
6. Horsman, S. (2008). Themes in official discourses on terrorism in Central Asia. Third World Quarterly, 26(1), 199-213. DOI: http://dx.doi.org/10.1080/01436590420003 22982.

7. Human Rights Watch (2005, May 13). Bullets are falling like rain. The Andijan Massacre, My 13, 2005. Human Rights Watch, 17, no. 5(D).

8. Human Rights Watch (2016, January 27). Central Asia: Backsliding on rights activists, groups targeted, persecuted by authorities. Human Rights Watch. Retrieved from https://www.hrw.org/news/2016/01/27/central-asia-backsliding-rights.

9. Institute for Economics and Peace (2016). Global Terrorism Index 2015. Institute for Economics and Peace.

10. International Crisis Group. (2001). Central Asia: Uzbekistan at 10 - repression and instability. International Crisis Group Asia Report, No. 21. International Crisis Group.

11. Jackson, R. D. W. (2007). The core commitments of critical terrorism studies. European Political Science, 6, 244-251. DOI: https://doi.org/10.1057/palgrave.eps.2210141.

12. Lain, S. (2016). Strategies for countering terrorism and extremism in Central Asia. Asian Affairs, 47(3), 386-405. DOI: https://doi.org/10.1080/03068374.2016.1225899.

13. Lewis, D. (2014). Crime terror and the state in Central Asia. Global Crime, 15(3-4), 337356. DOI: https://doi.org/10.1080/17440572.2014.927764.

14. NATO. (2002). North Atlantic Treaty Organization (Brussels, Belgium). Address by H.E. Islam Karimov, President of the Republic of Uzbekistan at the Euro-Atlantic Partnership Council, Prague Summit. Retrieved from https://www.nato.int/docu/ speech/2002/s021122a.htm.

15. Naumkin, V. (2005). Radical Islam in Central Asia: Between pen and rifle. Rowman \& Littlefield.

16. Nichol, J. (2010). Central Asia's security: Issues and implications for U.S. interests. In J. C. Tentas (Ed.), Security and internal affairs of Central Asia (pp. 1-95). Nova Science Publishers.

17. Omelicheva, Y. M. (2011). Counter-terrorism policies in Central Asia. Routledge.

18. Omelicheva, Y.M. (2007). Combating terrorism in Central Asia: Explaining differences in states' responses to terror. Terrorism and Political Violence, 19, 369-393. D0I: http://dx.doi.org/10.1080/09546550701424075.

19. Political Terror Scale. (1976-2015). PTS Data Table 1976-2015. Asheville, USA. Retrieved from http://www.politicalterrorscale.org/Data/Datatable.html.

20. Patnaik, A. (2016). Central Asia geo-politics security and stability. Routledge.

21. RAND (1994). RAND database of worldwide terrorist incidents. Retrieved from https://smapp.rand.org/rwtid/search.php.

22. Sevim, T. V., \& Rozanov, A. (2014). Ups and downs in foreign policy of Uzbekistan towards security approach of Russia. Khazar Journal of Humanities \& Social Sciences, $17(3), 18-33$.

23. START (2016). National Consortium for the study of terrorism and responses to terrorism (University of Maryland), Global Terrorism Database: Terrorist incidents 
of Uzbekistan 1992-2016. Retrieved from https://www.start.umd.edu/gtd/search/ Results.aspx? start_yearonly $=1992 \&$ end_yearonly $=2016 \&$ start_year=\&start_ month $=\&$ start_day $=\&$ end_year $=\&$ end_month $=\&$ end_day $=\& a s m S e l e c t 0=\& a s m S e l e c t 1$ $=\&$ criterion $1=$ yes $\&$ criterion $2=y e s \& c r i t e r i o n 3=y e s \& d t p 2=$ some $\&$ success $=y e s \&$ casualt ies_type $=\mathrm{b} \&$ casualties_max $=$.

24. UNDP (2014). Poverty, inequality, and vulnerability in the transition and developing economies of Europe and Central Asia. UNDP.

25. United Nations General Assembly. (2001). Abdulaziz Kamilov's, the Minister for Foreign Affairs of Uzbekistan addressed to the President. U.N. Doc. A/56/PV.54 annexe. Retrieved from http://www.un.org/ga/search/view_doc.asp?symbol=A/56/PV.54.

26. U.S. Department of State. (2000). Patterns of global terrorism 1999. Retrieved from https://1997-2001.state.gov/global/terrorism/1999report/patterns.pdf.

27. US Department of State. (2002). Annual Report on International Religious Freedom 2002. US Government Printing Office.

28. US Department of State. (2015). Country report on Terrorism. United States Department of State Publication.

29. Roth, A. (2016, September 2). Islam Karimov, Uzbekistan strongman who exploited anti-terror fight, dies at 78. The Washington Post. Retrieved from https://www.wa shingtonpost.com/world/islam-karimov-uzbekistan-strongman-who-exploited-antiterror-fight-dies-at-78/2016/09/02/3e08f846-7059-11e6-8365-b19e428a975e_ story.html.

30. Vidal, J. (2009, May 29). Global warming causes 300,000 deaths a year, says Kofi Annan thinktank. The Guardian, International Edition. Retrieved from https://www. theguardian.com/environment/2009/may/29/1.

31. WHO (2018). World Health Organization. Climate Change and Health. Retrieved from https://www.who.int/news-room/fact-sheets/detail/climate-change-and-health. 